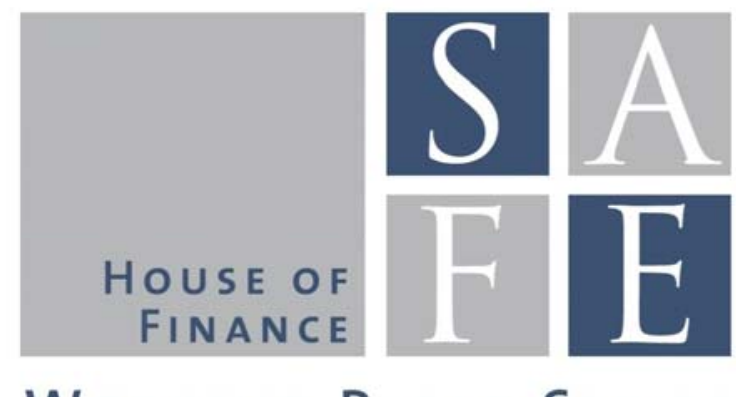

WORKING PAPER SERIES

Matthias Thiemann - Mohamed Aldegwy - Edin Ibrocevic

\title{
Understanding the Shift from Micro to Macro-Prudential Thinking: A Discursive Network Analysis
}

SAFE Working Paper No. 136

SAFE I Sustainable Architecture for Finance in Europe A cooperation of the Center for Financial Studies and Goethe University Frankfurt 


\title{
Understanding the Shift from Micro to Macro-Prudential Thinking: A Discursive
}

\section{Network Analysis}

\section{Matthias Thiemann, Mohamed Aldegwy and Edin Ibrocevic ${ }^{1}$}

\begin{abstract}
While some economists argued for macro-prudential regulation pre-crisis, the macro-prudential approach and its emphasis on endogenously created systemic risk have only gained prominence post-crisis. Employing discourse and network analysis on samples of the most cited scholarly works on banking regulation as well as on systemic risk (60 sources each) from 1985 to 2014, we analyze the shift from micro to macro-prudential thinking in the shift to the post crisis period. Our analysis demonstrates that the predominance of formalism, particularly, partial equilibrium analysis along with the exclusion of historical and practitioners' styles of reasoning from banking regulatory studies impeded economists from engaging seriously with the endogenous sources of systemic risk prior to the crisis. Post-crisis, these topics became important in this discourse, but the epistemological failures of banking regulatory studies precrisis were not sufficiently recognized. Recent attempts to conceptualize and price systemic risk as a negative externality point to the persistence of formalism and equilibrium thinking, with its attending dangers of incremental innovation due to epistemological barriers constrains theoretical progress, by excluding observed phenomena, which cannot yet be accommodated in mathematical models.
\end{abstract}

Keywords: Banking Regulation, Systemic Risk, Formalism, Equilibrium Thinking, Discourse and Citation Network Analysis

JEL Classification: B40, B41, G18, G28

\footnotetext{
${ }^{1}$ Matthias Thiemann is Juniorprofessor of Sociology of Finance, Goethe University, Frankfurt. Mohamed Aldegwy is a Doctoral Candidate at Goethe University, House of Finance, Frankfurt. Edin Ibrocevic is a graduate student. The first author contributed $50 \%$ to the paper, the second contributed $30 \%$ and the third contributed $20 \%$. Support by the SAFE Grant Do Basel III and the Dodd-Frank Act Reflect the Academic Debate on Macroprudential Regulation? Is gratefully acknowledged.
} 


\section{Introduction}

Since the outbreak of the financial crisis in 2007 , the macro-prudential policy paradigm has gained increasing prominence (BoE 2009; Bernanke 2011, Bisias et al 2012, Baker 2013, 2015). The pre-crisis consensus of focusing solely on the risk management of individual banks, based on the idea that "for the financial system to be sound it is necessary and sufficient that each individual institution is sound" (Borio 2009: 33, Crockett 2000) has been discredited. Instead, policy makers increasingly adopt the macro-prudential approach which focus on the systemic risks generated by the collective behavior of financial institutions (Crockett 2000, 3) and attempt to maintain the stability of the financial system as a whole through controlling these risks (Hanson et al 2011, Bisias et al 2012). While this shift in financial regulation has not been accompanied yet by a consensus on the appropriate measures and policy instruments (Baker 2013, Claessens and Kodres 2014), the trend towards macroprudential policy interventions seems irreversible (Baker 2015).

Despite the importance of this micro- to macro-prudential regulatory shift, the dynamics of this shift and the reasons that prevented this shift to take place prior to the crisis in the academic economic discourse have not been addressed systematically. Prior work has shown how the shift in economic theory from public to private interest regulation since the late 1960s has undergirded the decline of macro- and the growth of micro-prudential regulation in the following decades (Harnay and Scialom 2015). Our work carries this research forward by focusing on the evolution of the economic discourse on banking regulation since the late 1980s, contrasting it with the literature on systemic risk as the concept that undergirds macroprudential regulation (Bisias et al 2012). Investigating the reasons that impeded the shift from micro to macro-prudential regulation prior to the crisis, we identify the epistemological barriers that prevented the economic discourse on banking regulation to adopt a macro-prudential 
regulatory perspective pre-crisis. Investigating the micro-macro shift also allows us to point to the persistence of these reasons in the current conjuncture post-crisis.

The production of economic knowledge in academia influences policy making in financial regulation, particularly, due to the ongoing technocratization of the latter (Goodhart 2011). By focusing on the failures of the economic discourse that has fed into the policy sphere, our study complements prior studies that focused on the policy sphere alone (Baker, 2013, 2015, Seabrooke and Tsingou 2009, 2014). While these studies point to the importance of groups that act as carriers of ideas, their institutional standing as well as the alliances they enter into, they rather ignore the dynamics in the sphere of knowledge production itself. In this paper, to give these studies a better grounding in their discursive context, we investigate the sphere of economic discourse, i.e., the place where the cognitive models with which regulators were seeking to optimize regulation originated (Black 2013, Gigliobianci and Giordano 2012). We therefore analyze the most prominent writings of economists before the crisis on banking regulation, as they provided the intellectual input for the interpretative framework, the "policy paradigm" (Hall 1993, 279) in which regulatory policy was to be enacted. Our discourse analysis thus seeks to contribute to a better understanding of the role of economics in regulatory failures pre-crisis. The structure of this paper is as follows: Section 2 describes our method and samples. In section 3, we conduct the discourse and network analysis of our samples. Section 4 reflects on our findings and concludes.

\section{Method and Data Description}

We analyze the evolution of economic thinking about banking regulation and systemic risk in a longitudinal perspective through content and citation network analysis for the period from 1985 to 2014 . We collect the 10 top cited scholarly works per 5 year period on banking 
regulation. To understand whether and if so why this discourse has failed to take into account systemic risk prior to the crisis, we also trace the economic discourse on systemic risk for the same period, using a similar procedure. We consider the highest cited papers to be a good representative of the most influential and well-established ideas in the economic discourse on banking regulation in the years following their publication, during which these top cited articles have attracted most of their citations. Using the date of publications of these scholarly works, we divided the sample into six periods (1985-1989, 1990-1994, 1995-1999, 2000-2004, 20052009, and 2010-2014).

To collect the top cited works in each period, we used Google Scholar ${ }^{2}$ and searched for the following search terms in the "title" search: Banking Regulation, Bank Regulation, Financial Regulation, Microprudential Regulation, Micro-prudential Regulation, Microprudential, Macroprudential Regulation, Macro-Prudential Regulation, Macroprudential, and Banking Law. We have also used the following search terms in the whole article search in Google Scholar: Banking Regulation and Bank Regulation. For the systemic risk sample, we searched for titles in Google Scholar that include any of the terms: Systemic Risk, Financial Contagion, Bank Contagion, Banking Contagion, Banking Crisis, Financial Crisis, Bank Crisis, Financial Stability, and Financial Fragility. In the whole article search function, we searched for Systemic Risk, Financial Contagion, Financial Crisis, and Banking Crisis. In order to make sure that we did not miss any of the top cited scholarly works, we replicated the search above using the Web of Knowledge database.

The above search resulted in a generic sample of the top cited scholarly works that touch upon banking regulation and/or systemic risk, which we then refined by excluding the works that do

\footnotetext{
${ }^{2}$ We decided to use google scholar rather than Web of Science to avoid a selection bias caused by the focus on academic articles published in peer-reviewed academic journals. Thereby we could also include books and papers published by practitioners.
} 
not address banking regulation or systemic risk directly as being their key theme. However, we have not excluded the review articles that reached the top cited scholarly works in our banking regulation sample because they function as excellent proxies for the contemporary economic discourse on banking regulation; they reflect the economic discourse at the time of their publication and have influenced future research on banking regulation in the period following their publications. The final aggregate sample on systemic risk and banking regulation has 114 resources because six resources appear in both samples as these resources address directly both banking regulation and systemic risk. 
Kim, Santomero. 1988. Risk in Banking and Capital Regulation (733)

Jacklin, Bhattacharya. 1988 Distinguishing Panics and Information-based Bank Run (599)

Furlong, Keeley. 1989

Capital Regulation and Bank Risk-taking (461)

Diamond, Dybvig. 1986 Banking Theory, Deposit Insurance and Banking Reoulation

Spong. 1985. Banking Regulation: Its Purpose, Implementation and Effects (164)

Benston, Kaufman. 1988 Risk and Solvency Regulation of Depository Institution (163)

Fischel. 1989. The Regulation of Banks(155)

Baltensperger. 1987. Banking deregulation in Europe (107)

Keeley. 1988. Bank Capita Regulation in the 1980s (82)

Pyle. 1986. Capital regulation and Deposit Insurance (79)
Dewatripont, Tirole. 1994 The Prudential Regulation of Banks (1394)

Keeley. 1990. Deposit Insurance, Risk and Market Power in Banking (1588)

Freixas, Rochet. 1997. Microeconomics of Banking (2520)

Berger, Herring, Szegö. 1995. The Role of Capital in Financial Institutions (701)

Stiglitz. 1993. The Role of the Goodhart. 1998. Financial State in Financial Markets (1313)

Bhattacharya, Thakor. 1994. Contemporary Banking Theory (1061)

\section{Calomiris, Gorton. 1991. The Origins of Banking Panics (616) \\ Blum. 1999. Do Capital \\ Adequacy Requirements \\ Reduce Risks in Banking?}

Korszner, Rajan. 1994. Is the Glass-Steagall Act Justified? (504)

White. 1991. The S\&L Debacle (352)

Keeley, Furlong. 1990. A Reexamination of MeanVariance Analysis of Bank Canital Reoulation (317)

\section{Herring, Litan. 1994.}

Financial Regulation in the Global Economy (311)

Giammarino, Lewis. 1993 An Incentive Approach to Banking Regulation (166)

Regulation (520)

Bhattacharya, Boot, Thakor. 1998

The Economics of Bank Reoulation $(477$ (391)

Merton. 1995.Financia

Innovation and the

Management and Regulation

Peek, Rosengreen. 1995. Bank Regulation and the Credit Crunch (308)

Blum, Hellwig. 1995. The

Macroeconomic Implication

of Capital Adequacy (300)

Llwellyn. 1999. The

Economic Rationale for

Financial Regulation (255) (229) of Financial Institutions (323)

Besanko, Kanatas. 1996. The Regulation of Bank Capital
Hellmann, Murdock, Stiglitz 2000. Liberalization, Mora Hazard in Banking (1317)

Barth, Caprio, Levine. 2004. Bank Regulation and Supervision 1250)

Demirgüç-Kunt, Detragiache. Does Deposit Insurance Increase Banking System Stahilitv? ron7

Barth, Caprio, Levine. 2001. The Regulation and Supervision of Banks Around the World (748)

\section{Borio. 2003.}

Towards a Macroprudential

Framework for Financial Sunervision and Regulation?

Santos.2000. Bank capital Regulation in Contemporary Banking Theory (451)

Jones. 2000. Emerging Problems with the Basel Capital Accord (421)

Repullo. 2004. Capital

Requirements, Market Power and Risk-taking(386)

\section{Matutes, Vives. 2000}

Imperfection Competition, Risk

Taking, and Regulation in

Barth, Caprio, Levine. 2001.

Banking Systems Around the Globe (369)
Barth, Caprio, Levine. 2006 Rethinking Bank Regulation (843)

Brunnermeier, Crocket,

Goodhart, Hellwig, Persuad,

Shin. 2009. The Fundament Principles of Financial

Reoulation (805)

Borio, and Zhu. 2012 Capital Regulation, Risk-taking and Monetary Policy (470)

Admati, , DeMarzo, , Hellwig, and Pfleiderer.2011. Fallacies,

Irrelevant Facts, and Myths in the Discussion of Capital

Reoulation(399)

Laeven, Levine. 2009. Bank Governance, Regulation and Risk Taking (717)

Acharya. 2009. A Theory of Systemic Risk of Prudential Regulation (451)

Jimenez, Saurina. 2006.Credit Galati, Moessner. 2012.

Cycles, Credit Risk and Prudential Regulation (269)

Barth, Caprio, Levine. 2008. Bank Regulations are

Changing (239)

Allen, Carletti, Marquez. 2009. Credit Market Comnetition and Canita

VanHoose. 2007. Theories of Admati, Hellwig. 2014. The Bank Behavior under Capital Regulation (180)

\section{Gonzalez. 2005. Bank} Regulation and Risk-taking Incentives(179)

Borio, Shin 2007. What can (macro-)prudentialPolicy do to Sunnort Monetarv Policv?
Gorton, Metrick, Shleifer. 2010 Regulating the Shadow Banking Svstem (177)

Kashyap, and Stein.

11. A Macroprudentia

Approach to Financial Regulation (360)

Haldane, May. 2011. Systemic Risk in Banking Ecosystems(322)

Macroprudential Policy(237)

Beltratti, Stulz. 2012. The credi Crisis Around the Globe(181)

ankers New Clothes (161)

Haldane. 2010. A \$100 Billion Question? (139)

Clement 2010. The Term

"macroprudential": Origins and Evolutions (122)

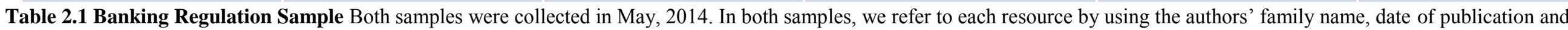

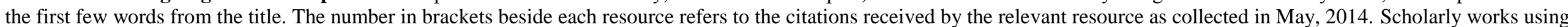

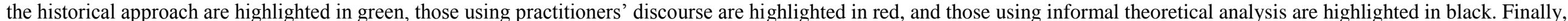
scholarly works using quantitative/formal methods, whether theoretical or empirical are highlighted in blue. 
Table 2.2 Systemic Risk Sample

\begin{tabular}{|c|c|c|c|c|c|}
\hline 1985-1989 & 1990-1994 & 1995-1999 & 2000-2004 & 2005-2009 & 2010-2014 \\
\hline $\begin{array}{l}\text { Mankiw. 1986. The } \\
\text { Allocation of Credit (423) }\end{array}$ & $\begin{array}{l}\text { Bhattacharya, Thakor. } \\
\text { 1993. Contemporary } \\
\text { Banking Theory (1061) }\end{array}$ & $\begin{array}{l}\text { Kaminsky, Reinhart. 1999. The } \\
\text { Twin Crises (4323) }\end{array}$ & $\begin{array}{l}\text { Allen, Gale. 2000. Financial } \\
\text { Contagion (2114) }\end{array}$ & $\begin{array}{l}\text { Brunnermeier. } 2008 . \\
\text { Deciphering the Liquidity and } \\
\text { Credit Crunch 2007-08 (1992) }\end{array}$ & $\begin{array}{l}\text { Adrian, Brunnermeier. } 2011 . \\
\text { CoVaR (986) }\end{array}$ \\
\hline $\begin{array}{l}\text { Schwartz. 1987. Real and } \\
\text { Pseudo-Financial Crises } \\
\text { (278) }\end{array}$ & $\begin{array}{l}\text { Bernanke, Gertler. } 1990 . \\
\text { Financial Fragility ( } 849)\end{array}$ & $\begin{array}{l}\text { Radelet, Sachs. 1998. The Onset } \\
\text { of the East Asian Financial Crisis. } \\
(2738)\end{array}$ & $\begin{array}{l}\text { Demirgüç-Kunt, Detragiache. } \\
\text { 2002. Does Deposit Insurance } \\
\text { Increase Banking System } \\
\text { Stability? (1317) }\end{array}$ & $\begin{array}{l}\text { Reinhart, Rogoff. 2008. Is the } \\
2007 \text { US Sub-prime Financial } \\
\text { Crisis so Different? (793) }\end{array}$ & $\begin{array}{l}\text { Gorton,Metrick. } 2012 . \\
\text { Securitized Banking and the } \\
\text { Run on Repo (655) }\end{array}$ \\
\hline $\begin{array}{l}\text { Taylor, O'Connel. 1985. A } \\
\text { Minsky Crisis (240) }\end{array}$ & $\begin{array}{l}\text { Minsky. 1992. The } \\
\text { Financial Instability } \\
\text { Hypothesis (702) }\end{array}$ & $\begin{array}{l}\text { Freixas, Rochet. } 1997 . \\
\text { Microeconomics of Banking } \\
(2515)\end{array}$ & $\begin{array}{l}\text { Borio,Lowe. 2002. Asset Prices, } \\
\text { Financial and Monetary } \\
\text { Stability (1190) }\end{array}$ & $\begin{array}{l}\text { Taylor. 2009. The Financial } \\
\text { Crisis and the Policy } \\
\text { Responses (779) }\end{array}$ & $\begin{array}{l}\text { Acharya, Pedersen, Philippon } \\
\text { Richardson. 2010. Measuring } \\
\text { Systemic Risk (548) }\end{array}$ \\
\hline $\begin{array}{l}\text { Gorton, Mullineux. } \\
\text { 1987. The joint production } \\
\text { of confidence. (173) }\end{array}$ & $\begin{array}{l}\text { Calomiris, Gorton. } 1991 . \\
\text { The Origins of Banking } \\
\text { Panics (614) }\end{array}$ & $\begin{array}{l}\text { Berger, Demsetz, Strahan. } 1999 . \\
\text { The Consolidation of the Financial } \\
\text { Services Industry (1324) }\end{array}$ & $\begin{array}{l}\text { Caprio, Klingebiel. } 2002 . \\
\text { Episodes of Systemic and } \\
\text { Borderline Banking }\end{array}$ & $\begin{array}{l}\text { Corsetti,Pericoli,Sbracia. } \\
\text { 2005. Some Contagion, Some } \\
\text { Interdependence (516) }\end{array}$ & $\begin{array}{l}\text { Gai, Kapadia. 2010. Contagion } \\
\text { in Financial Networks (332) }\end{array}$ \\
\hline $\begin{array}{l}\text { Eichengreen and Portes. } \\
\text { 1987. An Anatomy of } \\
\text { Financial Crises (149) }\end{array}$ & $\begin{array}{l}\text { Kaufman. 1994. Bank } \\
\text { Contagion (400) }\end{array}$ & $\begin{array}{l}\text { Demirgüç-KuntDetragiache1998a } \\
\text { The Determinants of Banking } \\
\text { Crises (1272) }\end{array}$ & $\begin{array}{l}\text { Kaminsky, Reinhart. 2000. On } \\
\text { Crises, Contagion, and } \\
\text { Confusion (1049) }\end{array}$ & $\begin{array}{l}\text { Beck, Demirgüç-Kunt, } \\
\text { Levine. 2006. Bank } \\
\text { Concentration, Competition }\end{array}$ & $\begin{array}{l}\text { Mendoza. 2010. Sudden Stops, } \\
\text { Financial Crises, and Leverage } \\
\text { (325) }\end{array}$ \\
\hline $\begin{array}{l}\text { Schwartz. 1988. Financial } \\
\text { Stability (100) }\end{array}$ & $\begin{array}{l}\text { Bernanke 1990. The Gold } \\
\text { Standard, Deflation and } \\
\text { Financial Crisis in the } \\
\text { Great Depression (335) }\end{array}$ & $\begin{array}{l}\text { Demirgüç-Kunt, Detragiache.b } \\
\text { 1998. Financial Liberalization and } \\
\text { Financial Fragility (1191) }\end{array}$ & $\begin{array}{l}\text { Bordo, Eichengreen, Klingebiel. } \\
\text { 2001. Is the Crisis Problem } \\
\text { Growing More Severe? (865) }\end{array}$ & $\begin{array}{l}\text { Schwarcz. 2008. Systemic } \\
\text { Risk. (462) }\end{array}$ & $\begin{array}{l}\text { Haldane, May. 2011. Systemic } \\
\text { Risk in Banking } \\
\text { Ecosystems(322) }\end{array}$ \\
\hline $\begin{array}{l}\text { Kindleberger. 1988. The } \\
\text { International Economic } \\
\text { Order - Essays on } \\
\text { Financial Crisis ( } 89 \text { ) }\end{array}$ & $\begin{array}{l}\text { Sundarajan, Balino. } 1991 . \\
\text { Banking Crises (191) }\end{array}$ & $\begin{array}{l}\text { Diamond, Rajan. 1999. Liquidity } \\
\text { Risk, Liquidity Creation and } \\
\text { Financial Fragility (1062) }\end{array}$ & $\begin{array}{l}\text { Borio, Furfine, Lowe, } \\
\text { Procyclicality of the Financial } \\
\text { System (791) }\end{array}$ & $\begin{array}{l}\text { Acharya. 2009. Theory of } \\
\text { Systemic (451) }\end{array}$ & $\begin{array}{l}\text { Laeven, Valencia. } 2013 . \\
\text { Systemic Banking Crises } \\
\text { Database (268) }\end{array}$ \\
\hline $\begin{array}{l}\text { Brimmer. Central Banking } \\
\text { and Systemic Risks in } \\
\text { Capital Markets (84) }\end{array}$ & $\begin{array}{l}\text { Calomiris. } 1993 . \\
\text { Financial factors in the } \\
\text { Great Depression (164) }\end{array}$ & $\begin{array}{l}\text { Goldstein. 1998. The Asian } \\
\text { Financial Crisis (751) }\end{array}$ & $\begin{array}{l}\text { Allen, Gale. 2000. Bubbles and } \\
\text { Crisis (788) }\end{array}$ & $\begin{array}{l}\text { Taylor, Williams. 2008. A } \\
\text { black Swan in the Money } \\
\text { Market (435) }\end{array}$ & $\begin{array}{l}\text { Shleifer, Vishny. } 2010 . \\
\text { Unstable Banking (255) }\end{array}$ \\
\hline $\begin{array}{l}\text { Tobin. 1986. Financial } \\
\text { innovation }(81)\end{array}$ & $\begin{array}{l}\text { Mishkin. } 1994 . \\
\text { Preventing Financial } \\
\text { Crisis (113) }\end{array}$ & $\begin{array}{l}\text { Caprio, Klingebiel. 1996. Bank } \\
\text { Insolvency (627) }\end{array}$ & $\begin{array}{l}\text { Freixas, Parigi, Rochet. } 2000 . \\
\text { Systemic Risk (680) }\end{array}$ & $\begin{array}{l}\text { Crotty. 2009. Structural } \\
\text { Causes of the Global Financial } \\
\text { Crisis (433) }\end{array}$ & $\begin{array}{l}\text { Brownless, Engle. } 2012 . \\
\text { Volatility, Correlations and } \\
\text { Tails for Systemic Risk }\end{array}$ \\
\hline $\begin{array}{l}\text { Balino. 1987.The } \\
\text { Argentine Banking Crisis } \\
\text { of } 1980 \text { (78) }\end{array}$ & $\begin{array}{l}\text { Park. 1991. Bank Failure } \\
\text { Contagion in Historical } \\
\text { Perspective (96) }\end{array}$ & $\begin{array}{l}\text { Rochet, Tirole. 1996. Interbank } \\
\text { Lending and Systemic Risk (611) }\end{array}$ & $\begin{array}{l}\text { De Bandt, Hartmann. } 2000 . \\
\text { Systemic Risk (663) }\end{array}$ & $\begin{array}{l}\text { Acharya, Richardson. } 2009 . \\
\text { Restoring Financial Stability } \\
\text { (397) }\end{array}$ & $\begin{array}{l}\text { Battiston, Gatti, Gallegatti, } \\
\text { Greenwald and Stiglitz. } 2012 . \\
\text { Liaisons dangereuses: } \\
\text { Increasing connectivity, risk } \\
\text { sharing, and systemic risk } \\
\text { (10) }\end{array}$ \\
\hline
\end{tabular}


The number of citations functions as a good proxy for the established ideas in the economic discourse unless some of the scholarly works are highly cited because their advocated ideas are rejected. Investigation of the banking regulation sample confirmed that the top cited works in each period share the same ideas. This qualitative finding is further confirmed by the hubs of the banking regulation network we identified using citation network analysis (s. below). The only outliers prior to the crisis were the articles of Borio (2003) and Jimenez and Saurina (2006), and these articles received most of their citations post crisis (s. below). In the systemic risk sample, ideas are more dispersed, however contestation only plays a limited role, as there is only very limited cross-citation in the systemic risk sample (s. below).

Once we compiled the data, we used qualitative discourse analysis (Mayring 2010) of the top five cited paper per period in each sample (30 resources per sample) to analyze the styles of reasoning, and the treatment of systemic risk in both samples. We focused on the origins of disturbances and chains of contagion in our analysis, the sources and propagation mechanisms of systemic risk. For the purpose of our discourse analysis, we distinguished between three sources of systemic risk that we distilled from the literature (Smaga 2014): bank runs, contagion and financial cycle. Individual bank runs caused by exogenous shocks are seen as the predominant source of systemic risk in the traditional neoclassical literature starting from Diamond and Dybvig (1983). Contagion/propagation risk, while exogenously generated, already has an endogenous element as contagion channels endogenously amplify the shock across the financial system (Smaga, 2014). Lastly, the financial/credit cycle is endogenously generated through the process of risk accumulation over time. The type of systemic risk underlying banking regulation is the crucial difference between the micro- and macro-prudential approach (cf. Crockett 2000) and it thus allows us to pinpoint which kind of understanding of systemic risk dominated each period of our samples. Furthermore, in our discourse analysis we 
focused on the particular styles of economic reasoning/methods underlying each scholarly work in our samples (for an indicative list of these styles, Crombie, 1994).

Based on the in-depth discourse analysis, we also coded the remaining 54 sources in terms of their discursive style and then applied citation network analysis to the aggregate sample of 114 sources. Network analysis is used to corroborate the findings of the discourse analysis, analyze the interrelations among both samples, and identify the central and authoritative papers in both samples. Here we draw on the distinction between hub measures and authority measures in citation network analysis. ${ }^{3}$ In the following we present our findings: first those common to both samples, then findings relevant to the banking regulation sample, findings relevant to the systemic risk sample, and finally, findings relevant to the relation between both samples.

\section{Discourse and Citation Network Analysis of Our Two Samples: Findings}

\subsection{Findings Common to Both Samples}

Our discursive analysis shows that some styles of reasoning in social sciences such as mixed methods and computational agent-based modelling are not adopted in both samples. The styles we observed in our samples can be categorized under two broad styles of reasoning: informal and formal analysis. We distinguished informal analysis further into three types: historically, theoretically and practically inspired discourses. With the exception of practitioners' style of reasoning, the styles of reasoning we observed in our samples (reported in table 3.1 below) are well-established and sufficiently distinct styles of reasoning in social sciences (Morgan 2012). Practitioners' style of reasoning however, does not easily fit into this well-established list.

\footnotetext{
${ }^{3}$ Scholarly works obtain a high hub value if they cite a lot of highly cited papers in the sample, whereas authorities are those scholarly works that are highly cited by other important papers. These measures reflect the importance of a paper in the network as the number of the out-and in-going ties are weighted with the importance of the paper to which a reference is made (Kleinberg 1999). Publications with high hub values can be analysed as synthesizing the current state of research, which is confirmed by the fact that most of the publications with high hub values in our sample are literature reviews (DeBandt, Hartmann 2000, Bhattacharya, Boot, Thakor 1998, Santos 2000). The authorities are considered as experts by the authors that form part of the network itself, usually because they contain novel, fundamental concepts for the literature on the topic.
} 
Rather, it seems akin to an engineering style of reasoning; it formulates its research question as a policy problem, and it uses a combination of empirics, informal and formal models, insights from historical cases, intuitions and judgments pragmatically for addressing this policy problem (for a defence of this style of reasoning as a guiding principle to economic policy making, Colander 2004).

\begin{tabular}{|l|l|l|}
\hline Style of Reasoning & Research Question & Method \\
\hline Informal Analysis: Historical & $\begin{array}{l}\text { To test theories with the } \\
\text { help of history and to } \\
\text { develop theories from } \\
\text { historical observations }\end{array}$ & $\begin{array}{l}\text {-Descriptive statistics and informal } \\
\text { modeling } \\
\text { - inductive }\end{array}$ \\
\hline $\begin{array}{l}\text { Informal Analysis: } \\
\text { Practitioners/technocrats }\end{array}$ & $\begin{array}{l}\text { Find a solution to a policy } \\
\text { concern }\end{array}$ & $\begin{array}{l}\text { Descriptive statistics, informal } \\
\text { theoretical analysis (eclectic) }\end{array}$ \\
\hline Informal Analysis: Theoreticians & $\begin{array}{l}\text { To explain and predict } \\
\text { system behavior }\end{array}$ & $\begin{array}{l}\text { Informal theoretical analysis: develop } \\
\text { and engage critically with economic } \\
\text { concepts and theories without models, } \\
\text { apply to regulation }\end{array}$ \\
\hline $\begin{array}{l}\text { Formal Analysis: Quantitative } \\
\text { Approach }\end{array}$ & $\begin{array}{l}\text { To explain and predict } \\
\text { system behavior }\end{array}$ & $\begin{array}{l}\text { Mathematical modeling and } \\
\text { econometrics }\end{array}$ \\
\hline
\end{tabular}

\section{Table 3.1: Different Styles of Reasoning/Discourses Observed in Our Samples}

These different discourses display a particular relationship to the conception of systemic risk and its analysis, as we will document below.

\section{Practitioners}

For practitioners, there is a non-problematic relationship to systemic risk. It is their major concern; concepts such as contagion represent an empirical reality they have to deal with, even allowing them to overstep the legal boundaries of their mandate (Brimmer1989). Practitioners' ease with the concepts of systemic risk and contagion also was an important source of legitimacy in the literature on systemic risk. Especially in the early literature (e.g. in the second period), one finds references by academics to practitioners to justify their theoretical work (e.g. on 
contagion, Kauffman 1994, also Bernanke and Gertler 1990). The style of practitioners, as found for example in the work of Kaminsky and Reinhart $(1999,2000)$ is to attempt to observe patterns in the data and to develop better forecasting of future events with its help. The practitioners' approach has been well summarized by John B. Taylor (2009): "Following an approach to policy advocated by David Dodge [the former Governor of the Bank of Canada] throughout his distinguished career in public service, I try to use empirical evidence to the maximum extent possible and explain the analysis in the simplest possible terms, including by using a series of illustrative graphs." (p. 3, emphasis ours).

\section{Historical discourse}

Scholars using historical reasoning/discourse, operate inductively based on the patterns they find in the historical data. Kindleberger (1988) for example seeks to develop models that fit these patterns. Other sources, such as Calomiris and Gorton (1991) focus on the historical origins of banking panics in the US (that is multiple bank runs and contagion effects) and discriminate between different theoretical models using this data. They thereby represent an old style of economics which was eclipsed by the rise of formal economic model building (cf. Kindleberger 1988). Remarkable in these sources is the use of simple flow charts, comparing countries over long periods of time as points of departure for theoretical reasoning.

\section{Informal analysts}

Informal analysts such as Borio (2003) and his group at the Bank of International Settlement (BIS), Brunnermeier (e.g. 2008) or Minsky ${ }^{4}$ (1992) seek to informally develop disequilibrium and endogenous risk models without being constrained by mathematical models. While they

\footnotetext{
${ }^{4}$ Similar to Borio (2003), Minsky's piece of 1992 titled 'The Financial Instability Hypothesis' enters our top cited articles in the second period of systemic risk sample only when we include the citations it receives post-financial crisis. If not, this piece cannot reach our top cited articles. This piece shares the informal discourse with the pieces of Borio, Brunnermeier, and Kindleberger.
} 
subject themselves to the rigor of mathematics where possible, they can work out the implications of financial cycle, and propagation risk without being constrained by formal models. It allows them to deal with more complex theoretical assumptions and thus to develop a broader picture of financial market developments. Informal analysts (such as Minsky) and historians (such as Kindleberger) relate to longer term empirical facts, which allow them to acknowledge the existence of repeating cycles.

\section{Formal Analysis}

In contrast, formal analysts rely primarily on mathematical models. That means that concepts only exist if they can be modelled. In the first four periods of both samples, mathematical modelling uses comparative statics, based on partial equilibrium. Formal analysts seek to explain financial fragility itself, but not how it can work over a cycle, basing themselves on exogenous shocks rather than endogenous build-up of risk (e.g. Bernanke and Gertler 1990). Models are made simple in order to keep them mathematically tractable. We observe a shift in methods and modelling techniques over the 6 periods covered, from partial equilibrium analysis to general equilibrium analysis and network analysis, both of which are better suited for thinking about systemic risk. This shift occurs around 2000 in the systemic risk sample, exemplified by the central work of Allen and Gale (2000). There is also a shift from comparative static analysis to dynamic analysis, as the time-dimension of risk is included when analyzing systemic risk (Borio 2003). These shifts in the modeling techniques towards network analysis and the dynamic analysis are the preconditions for the fundamental shift post-crisis. It allows for a broadening of real world phenomena that can be studied, such that mathematical modellers can more directly engage with systemic risk related concepts, such as contagion.

\section{The Distribution of the Different Styles in Both Samples}


When looking at the distribution of formal/informal discourses in the two samples, distinct differences emerge. Formal analysis dominates the banking regulation sample with a share of $61.64 \%$. Conversely, the informal discourses dominate the systemic risk sample with a share of $68.26 \%$ (s. table 3.2 )

\begin{tabular}{|c|c|c|c|c|}
\hline $\begin{array}{l}\text { Banking } \\
\text { regulation } \\
\text { Sample } \\
\end{array}$ & $\begin{array}{l}\text { Formal (Theoretical and } \\
\text { (econometrical) empirical }\end{array}$ & $\begin{array}{l}\text { Informal } \\
\text { Theoretical }\end{array}$ & Historical & $\begin{array}{l}\text { Practitioners' } \\
\text { discourse }\end{array}$ \\
\hline 1985-1989 & 7 & 3 & 0 & 0 \\
\hline 1990-1994 & 5 & 4 & 1 & 0 \\
\hline 1995-1999 & 8 & 2 & 0 & 0 \\
\hline $2000-2004$ & 8 & 2 & 0 & 0 \\
\hline 2005-2009 & 7 & 2 & 0 & 1 \\
\hline 2010-2014 & 2 & 8 & 0 & 0 \\
\hline Total & 37 & 21 & 1 & 1 \\
\hline \%share & $61,64 \%$ & $35 \%$ & $1,68 \%$ & $1,68 \%$ \\
\hline $\begin{array}{l}\text { Systemic } \\
\text { Risk } \\
\text { Sample }\end{array}$ & $\begin{array}{l}\text { Formal (Theoretical/econometrical) } \\
\text { empirical }\end{array}$ & $\begin{array}{l}\text { Informal } \\
\text { Theoretical }\end{array}$ & Historical & $\begin{array}{l}\text { Practitioners' } \\
\text { discourse }\end{array}$ \\
\hline $1985-1989$ & 2 & 1 & 5 & 2 \\
\hline $1990-1994$ & 2 & 4 & 2 & 2 \\
\hline 1995-1999 & 3 & 2 & 1 & 4 \\
\hline $2000-2004$ & 3 & 6 & 0 & 1 \\
\hline $2005-2009$ & 3 & 3 & 2 & 2 \\
\hline 2010-2014 & 6 & 3 & 1 & 0 \\
\hline Total & 19 & 19 & 11 & 11 \\
\hline \%share & $31,6 \%$ & $31,6 \%$ & $18,33 \%$ & $18,33 \%$ \\
\hline
\end{tabular}

Table 3.2 Distribution of styles of reasoning in both samples

In particular, there is a strong difference in the importance of the practitioners' and the historical styles in both samples. With a share of $1.68 \%$ for each style of the sample, receiving a total of 7 citations (historical) and 2 citations (practitioners) from the other sources, these styles are virtually absent in the banking regulation sample. In contrast, both have a share of $18.33 \%$ in the systemic risk sample and 26 and 31 citations respectively, showing that these sources with these two styles have a considerable influence in the systemic risk sample (s. table 3.3).

\begin{tabular}{|l|r|l|}
\hline Style/Sample & Systemic Risk Regulation \\
\hline Historical & Banking Regulation Sample & Sample: \\
\hline Informal & 7 & 26 \\
\hline
\end{tabular}




\begin{tabular}{|l|r|r|} 
Practitioner & 2 & 31 \\
\hline Formal & 131 & 41 \\
\hline
\end{tabular}

Table 3.3 Number of citations per style per sample

This difference in the importance of the practitioners' and historical style of reasoning becomes even more visible when one analyses density distribution of citations that is the likelihood that the sources in each period of our both samples would cite sources that use these particular styles of reasoning in the aggregate sample (s. table 3.4). Whereas sources using formal and informal theoretical analysis are most likely to be cited in the banking regulation sample, it is sources using practitioners or historical style that are most likely to be cited in the systemic risk sample. The overall likelihood of citing a practitioners' source is twice as high in the systemic risk sample as in the banking regulation sample. In contrast, the overall likelihood of a formal source being cited is more than twice as high in the banking regulation sample as in the systemic risk sample.

\begin{tabular}{|c|c|c|c|c|}
\hline $\begin{array}{l}\text { Period/Classification } \\
\text { Banking regulation } \\
\text { Sample. }\end{array}$ & Formal & $\begin{array}{l}\text { Informal- } \\
\text { theoretical }\end{array}$ & Historical & $\begin{array}{l}\text { Practitioners' } \\
\text { Style }\end{array}$ \\
\hline 1985-1989 & 0 & 0,017 & 0 & 0 \\
\hline 1990-1994 & 0,077 & 0,046 & 0,038 & 0 \\
\hline 1995-1999 & 0,109 & 0,076 & 0,022 & 0,056 \\
\hline 2000-2004 & 0,106 & 0,116 & 0,03 & 0,095 \\
\hline 2005-2009 & 0,054 & 0,024 & 0,008 & 0,017 \\
\hline 2010-2014 & 0,055 & 0,071 & 0,033 & 0,017 \\
\hline Total & 0,0668 & 0,058 & 0,0218 & 0,031 \\
\hline $\begin{array}{l}\text { Period/Classification } \\
\text { Systemic risk Sample }\end{array}$ & Formal & $\begin{array}{l}\text { Informal- } \\
\text { theoretical }\end{array}$ & Historical & $\begin{array}{l}\text { Practitioners' } \\
\text { Style }\end{array}$ \\
\hline 1985-1989 & 0 & 0 & 0 & 0 \\
\hline 1990-1994 & 0,038 & 0,015 & 0,087 & 0,075 \\
\hline 1995-1999 & 0,045 & 0,047 & 0,022 & 0,067 \\
\hline 2000-2004 & 0,058 & 0,03 & 0,045 & 0,178 \\
\hline 2005-2009 & 0,029 & 0,014 & 0,038 & 0,05 \\
\hline 2010-2014 & 0,016 & 0,008 & 0,02 & 0,008 \\
\hline Total & 0,031 & 0,019 & 0,035 & 0,063 \\
\hline
\end{tabular}


Table 3.4: Density distribution between Periods and Classifications for the banking regulation and the systemic risk sample. Density goes from periods towards classification

These differences in the distribution and the references to the different styles of discourse had a profound impact on the evolution of thinking about financial crises and systemic risk in the two samples, as we will show below.

\subsection{Findings Relevant to the Banking Regulation Sample}

As stated above, the banking regulation sample is dominated by formal reasoning, following mostly a partial equilibrium approach from 1985 to 2005. Starting from period five in the banking regulation sample, network analysis starts to appear as a style of reasoning. Scholarly works in the first period of the banking regulation sample (1985-1990) emphasized bank runs as the source of systemic risk and insolvency risk as the economic rationale for banking regulation. For addressing these regulatory problems, these scholarly works emphasized deposit insurance and capital requirements as the main banking regulatory instruments. They discussed the desirability of risk-sensitive capital regulation as non-risk related capital ratios may induce excessive risk taking by changing the composition of the asset side of the balance sheet. There was almost consensus that deposit insurance is almost the only solution for bank runs except in the case of money demand shocks, where lender of last resort or interbank markets can be appropriate alternatives. In this period, the term systemic risk has almost never been mentioned, and the contagion and financial cycle forms of systemic risk were not identified as key regulatory problems.

The works of the second and third periods of our banking regulation sample (1990-2000) are a natural extension of the works in the first period. The main new issue in the third period is debate regarding risk-based capital regulation, how to calculate it and its effects on the risk-taking incentives of banks. In line with this finding, papers with high hub values in the banking 
regulation sample (Bhattacharya et al 1998, Goodhart et al 1998, Santos 2000, Barth et al 2004) focus on the regulation of single institutions (with some minor exception by Goodhart et al 1998). Systemic risks are usually derived from the financial systems' vulnerability to suffer bank runs, based on information asymmetries (cf. Bhattacharya et al 1998), which in turn justifies deposit insurance, but only few sources engage multiple bank runs, that is panics (cf. Calomiris and Gorton 1991). In sum, the three first periods in the banking regulation sample (1985-2000) that were dominated by formal analysis witnessed very little theoretical developments.

In the fourth period authors question the previous consensus on deposit insurance as the optimal tool for addressing bank runs and panics (the only form of systemic risk tackled in banking regulation sample until this period), pointing to implicit deposit insurance as a more efficient risk management instrument. In addition they controversially debate the effects of banking liberalization and banking deregulation. Lastly, we observe the emergence of macro-prudential regulation in the fourth period of our sample (Borio 2003). However, this article has attracted most of its citations during the financial crisis years (143 citations from 2003-2007with an average citation of 28.6 per year, 542 citations from 2008 until September 2015 with an average citations of 67.75 per year).

The fifth period (2005-2009) of our sample is the period in which the shift from micro-to-macroprudential regulation occurs. In this period, three of the top cited articles explicitly tackle issues related to macro-prudential regulation (Acharya 2009; Jimenez and Saurina, 2006; Brunnermeier et al, 2009). The one study pre-crisis (Jimenez and Saurina 2006) is by two practitioners from the Bank of Spain and shows that credit growth in booms leads to increase of credit risk and higher percentage of non-performing loans. While the paper first appeared in January 2005, it received most of its citations post-crisis (27 citations over the three years preceding the crisis, with an average citations of 9 citations per year and received 357 citations 
from 2008 until September 2015with an average of 44.6 citations per year). This confirms that the shift to macro-prudential regulation took place post-crisis.

The works in the fifth period exemplify an important shift from the micro-prudential approach of the previous four periods (1985-2005). Research on banking regulation in this period has shifted form focusing on protection of investors to protection of markets, from focusing on analysis of individual banks to the analysis of interaction of multiple banks, and from static analysis, mainly taking the form of comparative statics to a dynamic analysis of risk and credit/financial cycles. Further, banking regulation research has shifted from partial equilibrium analysis and representative-bank models to network analysis and general equilibrium models. Most importantly, it has further shifted from the understanding of systemic risk based on bank runs to emphasize contagion and financial cycle sources of systemic risk.

The sixth period of our sample (2010-2014) is an exploratory phase of the macro-prudential regulatory paradigm. The top five cited articles in this period relate to macro-prudential regulatory questions. Scholars begin to use the cognitive perspective of the macro-prudential paradigm to pose new questions and to provide new answers to old questions. Substantively, the top cited articles began to provide a rationale for old regulatory instruments such as capital and liquidity ratios based on the contagion and financial cycle conceptions of systemic risk. As a result, they have made proposals for the amendment of these regulatory instruments to fit the macro-prudential perspective, through inter alia, counter-cyclical capital ratios, high quality capital and higher capital ratios. The economic rationale of macro-prudential banking regulation in this period relies on credit cycles, transmission channel of risk-taking, and the contribution of the financial institutions to credit crunch and fire-sales. Methodologically, scholars began to advocate a movement from partial equilibrium to a more focus on general equilibrium and network analysis. 
Despite these important changes at the methodological and substantive fronts, these changes have been formulated in the standard neoclassical language of market failures, where systemic risk itself has been conceptualized as a negative externality, to which individual banks contribute. The works of this period indicate that the endogenous model of systemic risk, which has been Minsky's initial idea (1992) and emphasized later by Borio (2003) seems to be the most challenging concept to model in comparison to systemic risk as a propagation risk (Galati, 2013). As scholars began to take macro-prudential regulation seriously, the common trait of studies at this period is that these studies are exploratory (Borio and Zhu 2012; Haldane 2011; Hanson et al. 2011) or of a review nature (Galati 2013). It is astonishing to find that the top five cited articles in the area of banking regulation are informal, given the highly formalized nature of the economic literature beforehand. As the new regulatory paradigm is unfolding, these papers explore new territory and set the stage for future research.

The exploratory informal nature of this period shows that informality may be required at exploratory phases of research, where informal discussions would naturally develop into semiformal, and formal ones. The financial crisis was required in order to lower the formalism barrier in economics with informal works being highly cited, setting the stage for more formal works to come, while illustrating failures of existing formal models. As such, informal thinking precedes formal thinking, and indicates to the temporary limitations of the latter. Formal theoretical works of our sample prior to the crisis were not able to engage with contagion or financial cycle sources of systemic risk and thus failed to discuss or recommend any macroprudential regulatory interventions. This is consistent with the failure of the same theoretical formal discourse to engage with these types of systemic risk in our systemic risk sample.

This internal closure is confirmed when looking at the Banking Regulation sample from a citation network analysis. It has a density of 0,048 and is thereby almost twice as dense as the entire network and the systemic risk sample indicating a rather visible community of banking 
regulation scholars. The fact that scholars who were organized around a clear research agenda, cross-citing each other can be seen from the fact that of the 60 sources of the banking regulation sample, it has only 5 isolates and only one source which is cited only once. Its biggest hubs are the scholarly works of Santos (2001) and Freixas and Rochet (1997), which are mathematical in nature. The five biggest authorities in the aggregate sample (Dewatripont and Tirole (1994), Berger Herring and Szegö (1995), Keeley (1990), Jacklin and Bhattacharya (1988) and Kim and Santomero (1988) are from the banking regulation sample; four of which are formal and all share the focus on micro-prudential regulation. Dewatripont and Tirole, while being informal in style, is rather conventional in content as it only engages with bank runs as the causes of systemic risk and focuses on the corporate governance principal-agent analysis for rationalizing banking regulation.

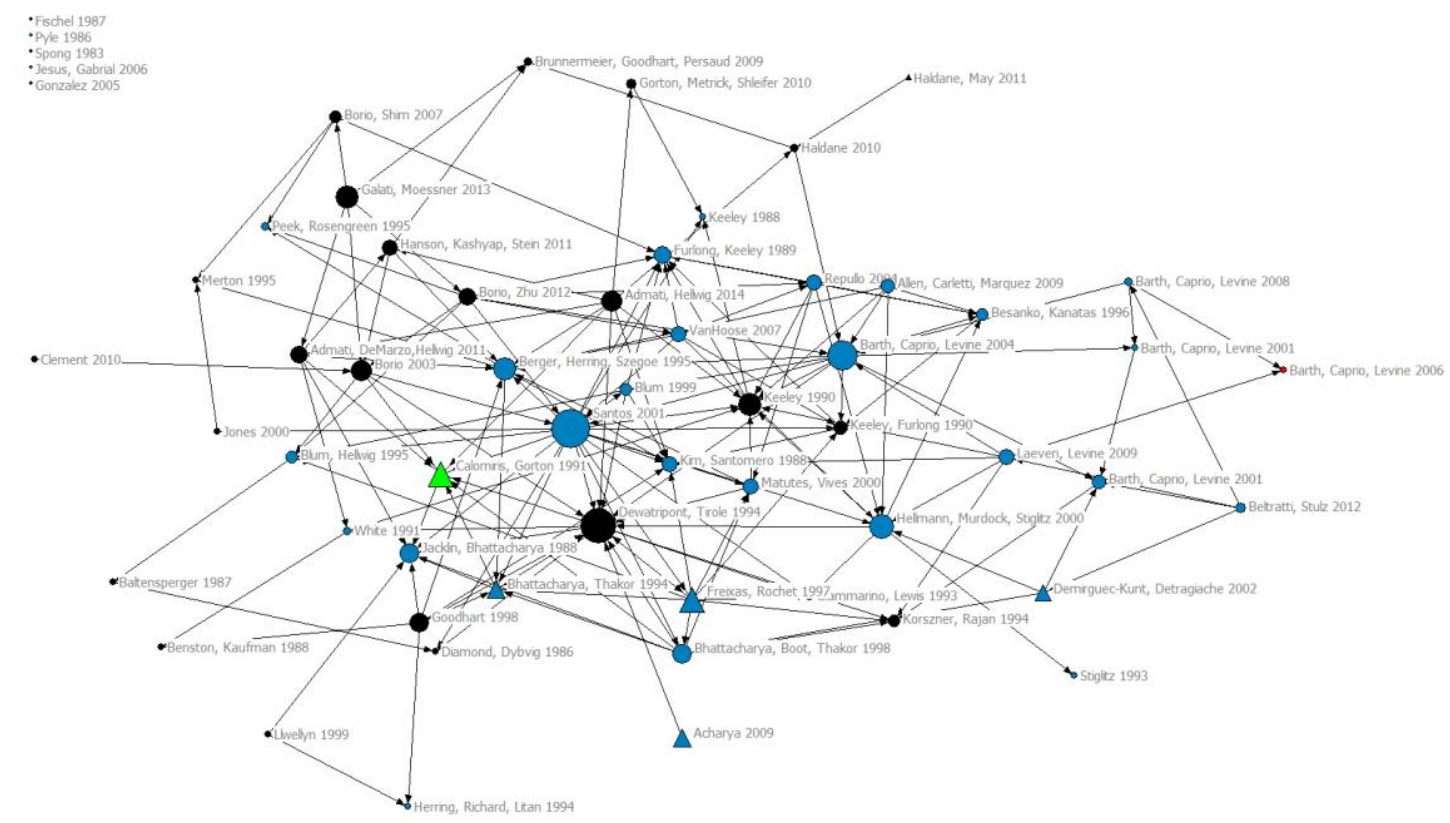

Figure 3.1: Banking Regulation Sample Network. Colours correspond to the colours in the tables 2.1 and 2.3.Banking regulation sources are depicted as circles. Sources common to both samples are depicted as triangles.

\subsection{Findings Relevant to the Systemic Risk Sample}


In contrast to the banking regulation sample, there is less thematic cohesion in the systemic risk sample. In the first period of our sample, systemic risk is discussed in historical terms in relation to the Great Depression and its lessons for potential deregulation in the present, where monetarists (Schwartz 1987) point to price level instability as the appropriate focus of regulatory action and Minskian scholars such as Kindleberger (1988) to fads in financial markets. The outliers to this debate are the formal analysis of Mankiw (1986) and Taylor, O'Connel (1985). A focus on contagion is also present in practitioners' discourses (Brimmer 1989), justifying Fed interventions in markets through concerns over possible contagion effects. In the first two sample periods, systemic risk is used as an intuitive concept related to financial crises. However, it does not receive a systematic definition until 1996 (Rochet and Tirole 1996, p. 733), and only after the crisis does it crystallize into a measurable format (e.g. Acharya 2009). Overall, the contagion effects of individual bank runs, that cause banking panics are seen as a main component of systemic risk in all the sources (e.g. Bhattacharya and Takor 1993, p. 26, Kaufman 1994), which leads to a strong coupling of the understanding of systemic risk and problems of liquidity (e.g. Freixas and Rochet 1997, Allen and Gale 2000).

While the notion of contagion is the centrally shared concept in the entire sample, Kaufman (1994) in the mid-1990s complains of a dearth of empirical studies, replaced by "causal empiricism", or just so stories (also Rochet and Tirole 1996, p. 734). This dearth of empirical work in our sample is only overcome with Kaminsky and Reinhart (1999) who study the interrelationship between banking and foreign exchange crises empirically. A major analytical step forward is taken by Allen and Gale (2000) as they demonstrate the capability to use network analysis as a conceptual and analytical tool to take into account the interbank deposit market. They are thus able to point to the structural factors which can turn a liquidity shock into a financial crisis, questions which are further developed in the coming 14 years (s. e.g. Gai and 
Kappadia 2010). Once the linkages of banks in terms of assets and liabilities are included in models, the problem of contagion can be modelled (Kaufmann 1994; Allen and Gale 2000). This allows for models of networks of banks linked via common exposure to assets with the danger of joint over-exposure, where systemic risk can be conceptualized as growing endogenously (Acharya 2009).

De Bandt and Hartmann's review of the work on systemic risk (2000) reflects this partial endogenization of systemic risk rather well. By focusing on the characteristics of the financial system as a whole that make it more vulnerable to systemic risk than other sectors, the interconnection of financial institutions are emphasized and contagion is placed at the heart of the concept of systemic risk (p. 8). In this way, they develop a broad concept of systemic risk that integrates systemic events in banking and financial markets as well as the payment and settlement system. At this point, the literature then mostly relates to the triggers and amplifying mechanisms operating during financial crises, but not to their causes. Around 2000, the question whether systemic risk is growing endogenously or exogenously is rather answered in favour of the latter, while at the same time modelling internal amplifying mechanisms. The endogenous position, which is strongly connected to the notion of financial cycles, booms and busts that are driven by self-reinforcing euphorias and panics (e.g. Kindleberger 1988, Calomiris and Gorton 1991, Minsky 1992, Kaminsky and Reinhart 1999, Borio 2002) only gains the upper hand after the financial crisis (Bisias et al 2012). Mathematical modellers up until 2007 remain agnostic on this issue as they undertake a simple comparative statics analysis using asymmetric information (e.g. Bernanke and Gertler 1990) or a structural comparison of network structures (Allen and Gale 2000) rather than a long-run cyclical analysis to analyse financial fragility. 
This different relationship to cycles between formal and informal analysis can very well be observed in the contribution by Bernanke and Gertler (1990), in which they seek to define the term "financial fragility". They develop a mathematical theory of how sudden credit squeezes can occur in the economy, based on an unexpected shock to the system. Using exogenous shocks to vary the leverage of borrowers and including moral hazard concerns allows them to generate more or less financial fragility in their model. Compared to the contributions of Minsky, Brimmer and Kindleberger of this period, what is remarkable is the different scope of the papers. Whereas the latter speak of cycles and longer term regularities, Bernanke and Gertler can only provide a mechanism of an economic shift in a snapshot-style. Questions of the financial cycles, of booms and busts are instead placed centre stage by informal analysts such as Kindleberger (1988) or Borio and Lowe (2002), but only received an empirical investigation starting with Reinhart and Rogoff (2008), who undertook simple historical analyses of the run-up to financial crises using charts and simple descriptive statistics. Given the simplicity of the analysis, this prior empirical gap in the literature on financial cycles can thus not be explained with mathematical difficulties. Rather we submit it can be accounted for by the devaluation of historical approaches in the field of financial economics. Whereas the style of the sources in the sample is predominantly informal in nature, this changes abruptly in the final period, when six of the ten sources are pursuing formal mathematical analysis to provide analytical measures for systemic risk.

Overall, there is a certain lack of thematic cohesion in the systemic risk sample, evidence of which is provided by the low density of the citation network for systemic risk (0.026 vs. 0.048 for banking regulation, figure 3.5 below), signalling a fragmented sub-area of research on systemic risk and the lack of a visible well-connected sub-community of scholars. The only hub of the systemic risk sample network is De Bandt and Hartmann (2000), connected to the three authorities in the systemic risk sample (Allen and Gale (2000A), Rochet and Tirole (1996) and 
Freixas, Parigi and Rochet (2000)), which are all formal. There are ten isolates and six sources which only receive one citation.

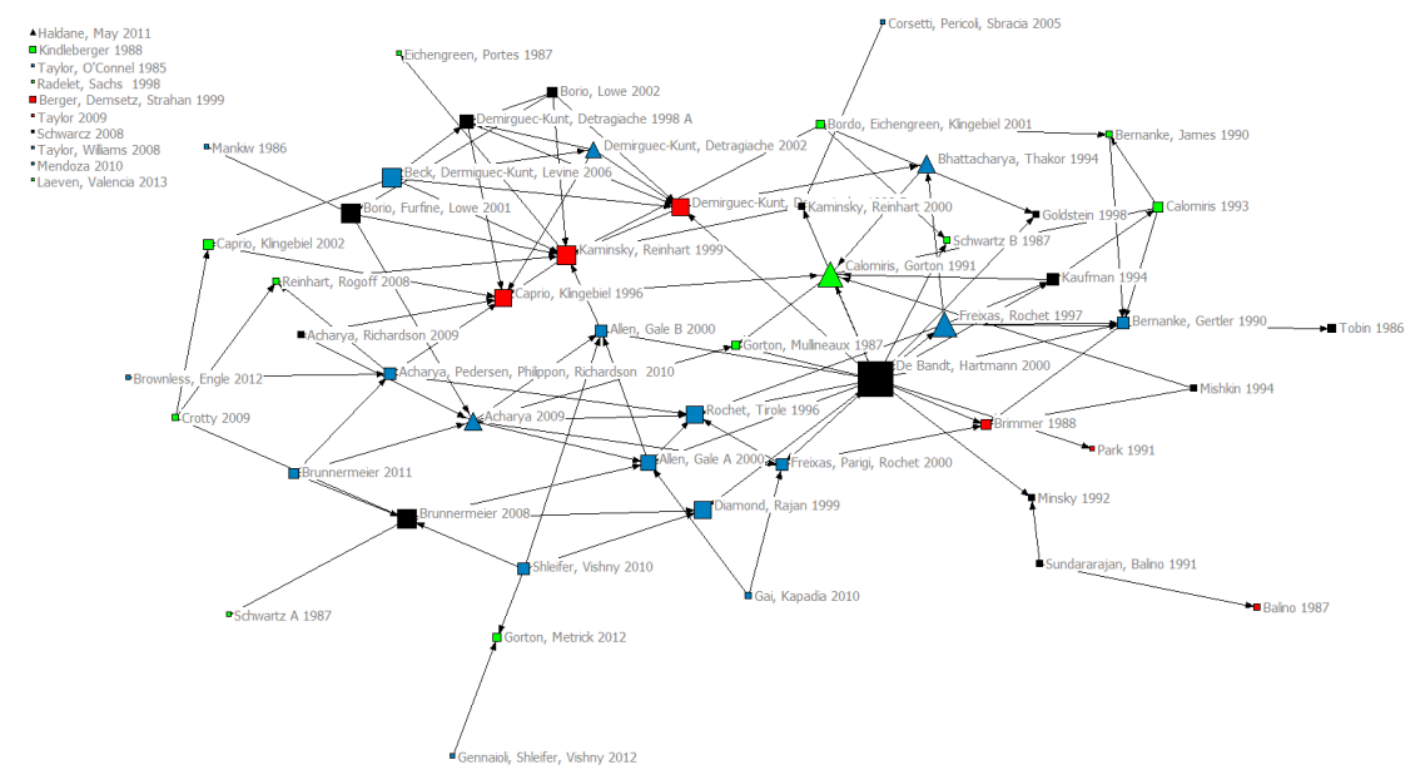

Figure 3.2 Systemic Risk Sample Network. Colors correspond to the colors in tables 2.1 and 2.3. Systemic risk sources are depicted as squares, while sources common to both samples are depicted as triangles.

\subsection{Findings Relevant to the Relation between Both Samples}

We have observed a strong disjunction between the systemic risk sample and the banking regulation sample prior to the crisis. Although some of the important ideas regarding contagion and the financial cycle as sources of systemic risk underlying the macro-prudential regulation were discussed starting from the first period in the systemic risk sample (e.g. Kindleberger 1988), these issues have only appeared, peripherally, in the fourth period of the banking regulation sample (2000-2004), and taken hold starting from the shift from micro- to macroprudential regulation period (2005-2009). Pre-crisis, scholars in the banking regulation 
sample simply did not engage with the informal discourse on systemic risk, citing it only to justify their own work.

In order to corroborate the thematic disjunction between the two samples, we analyzed the overall network formed by the two samples. Overall, the number of citations linking the two samples is 60 . Citations primarily go from the banking regulation sample to the systemic risk sample (42 vs. 18). The density between the samples is 0,016 compared to the overall density of the network of 0,026 , indicating a lower connectivity between the two samples than in the overall network and inside of the two samples. A closer look at the incoming citations received by the works in the systemic risk sample from the banking regulation sample shows the precrisis disjunction in more detail. Out of the 42 citations, 23 appeared from 2008 onwards (after the paradigm shift) with an average citation of 2.875 per year, leaving 19 before the crisis with an average citations of 0.826 per year.

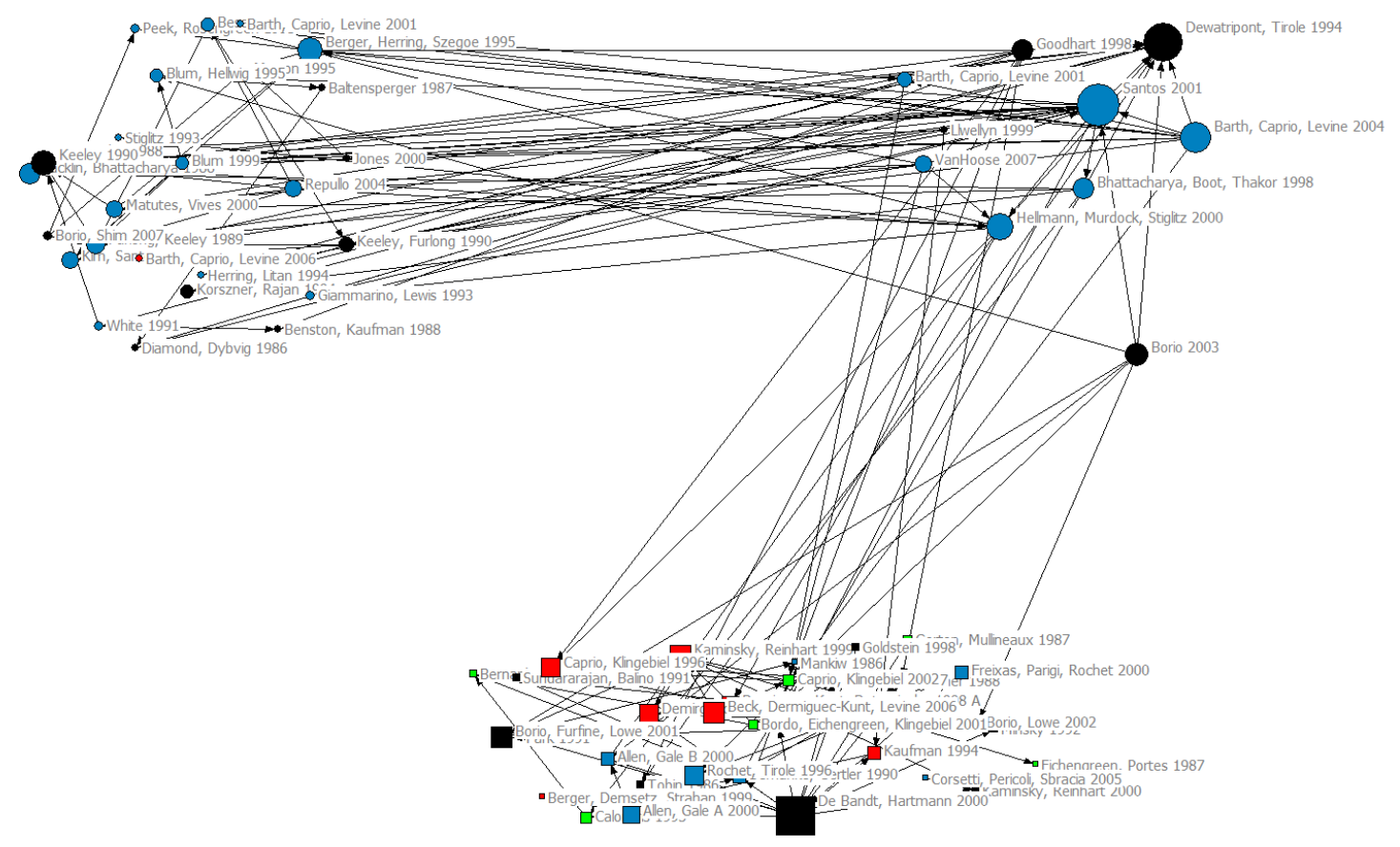

Figure 3.3 Citations from the Banking regulation sample to the systemic risk sample pre-crisis 
Four citations are made by Borio (2003), a macroprudentialist figure whose source is only in the banking regulation sample due to its post-crisis popularity. An analysis of the 15 genuine citations by ten sources (portrayed on the right hand side of figure 3.3 above) showed that the only case in which a concept/result from the systemic risk sample was adopted by the banking regulation sample was by Hellmann, Murdock and Stiglitz (2000), when quoting both works by Demirguec-Kunt and Detragiache (1998 a, b) which show an increasing frequency of financial crises in the past decades. The paper by Hellmann et al (2000) then seeks to provide a rationale for this occurrence, linking it to capital market liberalization. The other 13 citations are either in literature reviews, cited in passing or as historic evidence of past crisis.

This disjunction can be linked to the fact that the endogenous sources of systemic risk, although discussed more seriously in the systemic risk sample, have not been well-conceptualized or quantified in the early three periods. The formal nature of banking regulation research at that time then might explain why due to its lack of formalization these ideas were not taken up. This mismatch between the predominant styles in the two discourses is confirmed by the dominance of informal theoretical analysis in the last period of the banking regulation sample, at the same time that the formal analysis in the systemic risk sample becomes predominant. The macroprudential analytical framework cannot be included in the formalized discourse on banking regulation without an underlying formalization and quantification of systemic risk. Given the absence of such formalization, scholars try to develop it, while texts in the banking regulation sample informally explore macro-regulatory issues, awaiting such formalization. In this sense, the recent developments in both samples signal a rapprochement of the two discourses. However, the use of mathematical models may well continue to be a problem, caused by the incremental nature of many of the mathematical economists' contributions. This can be seen from a comparison of formal and informal analysts. Informal analysts could think about and 
discuss propagation/contagion and financial cycle as sources of systemic risk, whereas quantitative scholars could not establish a conversation without a model, and thus were much more reticent to include these concepts in their discourse. In this sense, mathematical models constituted epistemological barriers and constrained theoretical progress, by excluding observed phenomena, which could not yet be accommodated in mathematical models.

\section{Conclusion}

This paper traced the evolution of the economic discourses on systemic risk and banking regulation to better understand the shift from micro to macro-prudential banking regulation. Our samples show that the informal-theoretical, historical and practitioners' subsets of the economic discourse on systemic risk were able to discuss the contagion and financial cycle forms of systemic risk whereas the formal theoretical subset of the economic discourse, particularly, of the banking regulation sample overlooked these types of systemic risk almost completely precrisis. Why did they ignore it?

One evident reason was the rather late conceptualization, measurement and operationalization of systemic risk, which did not make it amenable to the predominantly formal analysis in the banking regulation sample. A second one is the impact of the initial model of bank runs operating with one representative bank (Rochet and Tirole 1996, 733f). This model made the analysis of contagion channels other than the informational channel by definition impossible, as the tractability of the Diamond/Dybvig model from 1983 was achieved by mathematical simplification. Unfortunately, Kindleberger's remark that "it is not evident that the historical record should be set aside in favour of easier mathematics" was ignored $(1988,91)$. This communicative closure in mathematical economics, where concepts only exist if they can be included in a mathematical model (a trade-off between rigor and relevance extensively 
discussed in the economic methodology literature, see, e.g. Backhouse 1998; Blaug 2009) then partially explains our finding regarding the relation between both samples.

But the failure of the discourse on banking regulation to engage with these sources of systemic risk pre-crisis cannot solely be attributed to being locked into formalism, as the literature was locked into a specific form of modelling, mainly non-structural partial equilibrium analysis. Formal network analysts were able to pinpoint endogenous sources of systemic risk prior to the crisis using mathematical means (most prominently Allen and Gale 2000). Formalism in economic discourse becomes particularly constraining when it only includes a specific very limited number of approaches. Our analysis thus substantiates the failure of equilibrium thinking of neoclassical economics in capturing disequilibrium processes, particularly, crises (cf. Arthur 2013).

This brings us to explore why practitioner's and historical approaches were able to engage with contagion and financial cycles as sources of systemic risk. We suggest that these discourses enable scholars to gain forms of knowledge that the formal theoretical approaches may fail to produce. Being guided by the empirical data, historical and practitioner's approaches do not interpret the data by using the theoretical lens of partial or general equilibrium analysis. Rather, once they perceive the system to be repeatedly in disequilibrium as revealed in the regularities in the data, they begin to think eclectically about the sources of this risk, how it accumulates and how it could be addressed. These informal approaches, being empirically oriented, allow scholars to see what theoreticians of equilibrium models can hardly see. Freed from the neoclassical theoretical assumptions, scholars can proceed on the basis of hypotheses that are inconsistent with neoclassical theories (such as endogenous risk) to address these anomalies. 
This is the major strength of these approaches over formal theoretical approaches, particularly, when they either cannot see or accommodate these anomalies into their models.

Further, systemic risk as an endogenous phenomenon of the system postulates a level that extends beyond the individual where risks may accumulate, independent of or maybe even because of rational action of actors at the micro-level (Baker 2013). This contradicts the neoclassical paradigm that assumes macro-level order based on rational action at the microlevel (Harnay and Scialom 2015). The concept of systemic risk then was hardly reconcilable with the neoclassical theoretical frame, leaving proponents of the theory bereft of the possibility to use the theoretical mainstream for inspiration. This explanation is consistent with the theorization of systemic risk as a negative externality in the fifth and sixth phase of the banking regulation sample, which tries to subsume the concept of systemic risk within the neoclassical market failure paradigm (Acharya et al 2010), rather than rethinking the concept as an emergent property of the financial system (Haldane 2011).

In conclusion, our discourse analysis has shown that formal theoretical analysis coupled with the exclusion of practitioners' and historical approaches from banking regulatory studies have impeded the evolution of macro-prudential regulation prior to the crisis. The economic discourse on banking regulation pre-crisis, dominated by formalism was driven by problems that could be modelled given the predominant formal methods, rather than being concerned with the problems practitioners face. The fact that the post-crisis samples on banking regulation have been exploratory and informal in nature shows that informalism was needed for developing macro-prudential thinking. Certain forms of formalism, particularly, non-structural partial equilibrium analysis has intensified the obstacles to the evolution of a macro-prudential paradigm prior to the crisis. The sharp rise of formal studies in the last period of our systemic 
risk sample signals a shift to formalism at the cost of informal styles of reasoning. The danger is that scholars, not cognizant of the methodological limitations that prevented them from engaging with contagion and the financial cycle in the first place now reproduce these limitations when tackling them post-crisis. 


\section{Bibliography}

Acharya, V. V. (2009). A Theory of Systemic Risk and Design of Prudential Bank Regulation.Journal of Financial Stability 5, 224-255.

Allen and Gale. (2000). Financial Contagion. Journal of Political Economy 108, 1-33

Arthur W. B. (2013), Complexity Economics: A Different Framework for Economic Thought. Sante Fe Working Paper 2013-04-012, available at:

http://www.santafe.edu/media/workingpapers/13-04-012.pdf Access: August 10th, 2015.

Backhouse, R. E. (1998) If Mathematics is Informal, Then Perhaps We Should Accept That

Economics Must be Informal Too. The Economic Journal 108 (451).

Baker, A. (2013). The New Political Economy of the Macroprudential Ideational Shift. New Political Economy 18 (1),112-139.

Baker, A. (2015). Varieties of Economic Crisis, Varieties of Ideational Change: How and Why Financial Regulation and Macroeconomic Policy Differ? New Political Economy,20:3, p.342366

Bank of England (2009).The Role of Macroprudential Policy.Discussion paper.Bank of England.

Barth, Caprio and Levine. (2004). Bank regulations and supervision: what works best?. Journal of Financial Intermediation 13, 205-248.

Berger, Herring and Szegö. (1995). The role of capital in financial institutions. Journal of Banking \& Finance 19, 393-430

Bernanke, B. S.(2011). Implementing AMacroprudential Approach to Supervision and Regulation.Resource document.47th Annual Conference on Bank Structure and Competition, Chicago, Illinois.http://www.federalreserve.gov/newsevents/speech/bernanke20110505a.htm Access: May 5 ${ }^{\text {th }}, 2014$. 
Bernanke, B. andGertler, M. (1990). Financial Fragility and Economic Performance.The Quarterly Journal of Economics 105, 87-114.

Bhattacharya, Boot and Thakor. (1998). The Economics of Bank Regulation. Journal of Money, Credit and Banking 30, 745-770

Bhattacharya and Thakor. (1993).Contemporary Banking Theory. Journal of Financial Intermediation 3, 2-50

Black, J. (2013). Seeing, Knowing, and Regulating Financial Markets: Moving the Cognitive Framework from the Economic to the Social. Resource document. LSE Law, Society and Economy Working Papers 24/2013. http://www.lse.ac.uk/collections/law/wps/WPS201324_Black.pdfAccess 10.09.2014.

Bisias et. al. (2012). A Survey of Systemic Risk Analytics. Office of Financial Research, U.S. Department of the Treasury.

Blaug, M. (2009) The Trade-Off between Rigor and Relevance: Sraffian Economics as a Case in Point. History of Political Economy (41) 2.

Borio, C. (2003). Towards a Macroprudential Framework for Financial Supervision and Regulation?. CESifo Economic Studies 49, 181-215

Borio, C. (2009). Implementing the Macroprudential Approach to Financial Regulation and Supervision.Financial Stability Review 13.

Borio and Lowe. (2002), Asset prices, financial and monetary stability: exploring the nexus. BIS Working Papers No 114.

Borio, C. and Zhu, H. (2012). Capital Regulation, Risk-taking and Monetary Policy: A Missing Link in the Transmission Mechanism? Journal of Financial Stability 8, 236-251. Brimmer, A. F. (1989). Distinguished Lecture on Economics in Government: Central Banking and Systemic Risks in Capital Markets. The Journal of Economic Perspectives, 3-16. 
Brunnermeier, M. (2008). Deciphering the Liquidity and Credit Crunch 2007-08. National Bureau of Economic Research, Working Paper 14612

Brunnermeier, M., Crockett, C., Persaud, A.D. and H. S. Shin, (2009). The Fundamental Principles of Financial Regulation: Geneva Reports on the World Economy. London, Washington: Centre for Economic Policy Research; Brookings Institution Press.

Calomiris, C. W. and Gorton, G. (1991). The Origins of Banking Panics: Models, Facts and Bank Regulation. In G. R. Hubbard (ed.), Financial Markets and Financial Crises. Chicago: University of Chicago Press, pp. 109-174

Colander, D. (2004).From Muddling Through to the Economics of Control: View of Applied Policy from J.N. Keynes to Abba Lerner. Middlebury College Economics Discussion Paper No. $04-21$

Crockett, A. (2000). Marrying the micro- and macro-prudential dimensions of financial stability. Speech at the Eleventh International Conference of Banking Supervisors Crombie, A. (1994). Styles of Scientific Thinking in the European Tradition, 3 vols.London: Duckworth.

De Bandt and Hartmann (2000). Systemic Risk: A Survey. European Cenral Bank Working Paper Series No. 35.

Dewatripont and Tirole. (1994). The Prudential Regulation of Banks. Cambridge, Massachusetts: The MIT Press

Diamond and Dybvig. (1983). Bank Runs, Deposit Insurance, and Liquidity. Journal of Political Economy, 91, 401-419.

Freixas, Parigi and Rochet. (2000). Systemic Risk, Interbank Relations, and Liquidity Provisions by the central Bank. Journal of Money, Credit and Banking 32, Part2: What Should Central Banks Do?, 611-638. 
Freixas and Rochet. (1997). Microecomoics of Banking. Cambridge, Massachusetts: The MIT Press

Gai and Kappadia. (2010). Contagion in financial networks. Proceedings of the Royal Society Vol. 466 Issue: 2120.

Galati. (2013). Macroprudential Policy - A Literature Review. Journal of Economic Survey $27,846-878$.

Galati, G. and Moessner, R. (2012).Macroprudential Policy - a Literature Review.Journal of Economic Surveys 27, 846-878.

Gigliobianco, Alfredo, and Claire Giordano. 2012. "Does economic theory matter in shaping banking regulation? A case-study of Italy (1861-1936)."Accounting, Economics, and Law 2.1

Goodhart, C. 2011.The Basel committee on banking supervision: A History of theEarlyYears 1974-1997. Cambridge: Cambridge University Press

Goodhart et al. (1998), Financial Regulation: Why, How and where Now?. New York, New York: Routledge.

Haldane, A. G. and May, R. M. (2011).Systemic Risk in Banking Ecosystems.Nature 469, $351-355$.

Hall, P.A. (1993) 'Policy paradigms, social learning, and the state: the case of economic policymaking in Britain', Comparative Politics 25: 275-96

Hanson, S., Kashyap, A., and Stein, J. (2011).A Macroprudential Approach to Financial Regulation.Journal of Economic Perspectives 25, 3-28.

Harnay and Scialom (2015). The influence of the economic approaches to regulation on banking regulations: A short history of banking regulations". Cambridge Journal of Economics 
Hellmann, Murdock and Stiglitz. (2000). Liberalization, Moral Hazard in Banking, and Prudential Regulation: Are Capital Requirements Enough?. The American Economic Review, 90, 147-165.

Jacklin and Bhattacharya. (1988). Distinguishing Panics and Information-based Bank Runs: Welfare and Policy Implications. Journal of Political Economy 96, 568-592.

Jimenez, G. and J. Saurina, J. (2006). Credit cycles, credit risk, and prudential regulation. International Journal of Central Banking, pp. 65-98

Kaminsky, G. L. and Reinhart, C. M. (2000).On Crises, Contagion, and Confusion.Journal of International Economics 51, 145-68.

Kaminsky, G. L. and Reinhart, C. M. (1999). The Twin Crises: the Causes of Banking and Balance-of-Payments Problems. American Economic Review 89 (3), 473-500.

Kaufman, G. G. (1994). Bank Contagion: A Review of the Theory and Evidence. Journal of Financial Services Research 8, 123-150.

Keeley. (1990). Deposit Insurance, Risk, and Market Power in Banking. The American Economic Review 80, 1183-1200.

Kim and Santomero. (1988). Risk in Banking and Capital Regulation. The Journal of Finance $43,1219-1233$.

Kleinberg, J. (1999). Authoritative Source in a Hyperlinked Environment.Journal of the ACM. Nr.5 S. 603-632.

Kindleberger, C. P. (1988). The International Economic Order.Essays on Financial Crisis and International Public Goods. Hempstead: Harvester Wheatsheaf.

Mankiw. (1986). The Allocation of Credit and Financial Collapse. Quarterly Journal of Economics 101, 455-470.

Mayring, Philipp. Qualitative Inhaltsanalyse. VS Verlag für Sozialwissenschaften, 2010. 
Minsky, H. P. (1992).The Financial Instability Hypothesis. The Jerome Levy Economics Institute Working Paper.

Morgan, M. S. (2012). The World in the Model: How Economists Work and Think.

Cambridge, New York: Cambridge University Press.

Reinhart and Rogoff. (2008). This time is Different: A Panoramic View of Eight Centuries of Financial Crises. Annals of Economics and Finance 15, 1065-1188

Rochet and Tirole. (1996). Interbank Lending and Systemic Risk. Journal of Money, Credit and Banking 28, Part 2: Payment Systems and Public Policy Risk, Efficiency, and Innovation, 733-762.

Santos. (2000). Bank Capital Regulation in Contemporary Banking Theory: A Review of the Literature. Financial Markets, Institutions \& Instruments 10, 41-84

Schwartz, A. Real and Pseudo-Financial Crises In Anna J. Schwartz (editor). Money in Historical Perspective. Chicago: University of Chicago Press, p. 271 - 288

Seabrooke, L. and E. Tsingou. 2014. Distinctions, affiliations, andprofessional knowledge in financial reform expert groups. Journal of European Public Policy Volume 21, No. 3, 389-407 Seabrooke, L. and E. Tsingou. 2009. Revolving Doors and Linked Ecologies in the World Economy:Policy Locations and the Practice ofInternational Financial Reform. Centre for the Study of Globalisation and Regionalisation Working Paper 260/09 Smaga, P. (2014). The Concept of Systemic Risk. Systemic Risk Centre Special Paper No 5, The London School of Economics and Political Science, August 2014. Available at: http://ssrn.com/abstract=2477928 Access: September $13^{\text {th }}, 2015$

Taylor, J. B. (2009). The Financial Crisis and the Policy Responses: An Empirical Analysis of What Went Wrong.Resource document.Social Science Research Network.http://papers.ssrn.com/sol3/papers.cfm?abstract_id=1327252 Access: 08.08.2014. 
Taylor and O'Connel. (1985). A Minsky Crisis. The Quarterly Journal of Economics 100, 871885. 


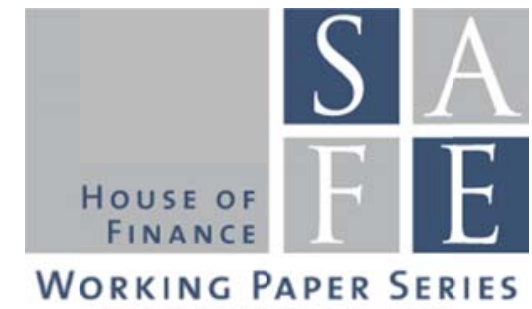

\section{Recent Issues}

No. 135 Douglas Cumming, Jochen Werth, Yelin Zhang

No.134 Markus Kröll, Devesh Rustagi

No. 133 Markus Behn, Rainer Haselmann, Thomas Kick, Vikrant Vig

No. 132 Rainer Haselmann, David Schoenherr, Vikrant Vig

No.131 Nicole Branger, Patrick Grüning, Christian Schlag

No. 130 Giuliano Curatola

No.129 Giuliano Curatola, Michael Donadelli, Patrick Grüning, Christoph Meinerding

No. 128 Giuliano Curatola

No. 127 Helmut Elsinger, Philipp SchmidtDengler, Christine Zulehner

No. 126 Carsten Bienz, Karin S. Thorburn, Uwe Walz

No. 125 Tobias H. Tröger, Uwe Walz

No. 124 Adrian Buss, Bernard Dumas, Raman Uppal, Grigory Vilkov

No. 123 Marie Lalanne, Paul Seabright

No. 122 Douglas Cumming, Uwe Walz, Jochen Werth
Governance in Entrepreneurial Ecosystems: Venture Capitalists vs. Technology Parks

Got Milk? Motivation for Honesty and Cheating in Informal Markets: Evidence from India

The Political Economy of Bank Bailouts

Rent-Seeking in Elite Networks

Commodities, Financialization, and Heterogeneous Agents

Optimal Consumption and Portfolio Choice with Loss Aversion

Investment-Specific Shocks, Business Cycles, and Asset Prices

Preference Evolution and the Dynamics of Capital Markets

Competition in Treasury Auctions

Coinvestment and risk taking in private equity funds

Does Say on Pay Matter? Evidence from the German Natural Experiment

The Intended and Unintended Consequences of Financial-Market Regulations: A General Equilibrium Analysis

The Old Boy Network: The Impact of Professional Networks on Remuneration in Top Executive Jobs

The Dynamics of Entrepreneurial Careers in High-Tech Ventures: Experience, Education, and Exit 